\title{
Gellnerova islamika
}

\author{
LUBOŠ KROPÁČEK*
}

Gellner's Islamics

\begin{abstract}
Ernest Gellner took a great interest in the functioning of Muslim society, which he liked to put in contrast to Western values and social patterns. The article deals with his approach to five topical areas. The first one is his well-known theory of two forms of Islam whose age-long oscillation was stopped in modern times by the triumph of the higher, more individualist version. The ensuing growth of Islamic fundamentalism is further explained within Gellner's interpretation of this concept in a general philosophical meaning. Other topics comprise nationalism in Muslim societies, discussion on the controversial issue of acceptability of civil society in the world of Islam and, finally, Gellner's attempt to explain the astonishing collapse of Marxism in 1990s in contrast with the success of the unsecularized modernity of Islam. The paper provides room for critical approaches to Gellner's views, their week point being mainly ahistorical generalizations neglecting broader patterns of Muslim societies and their trends. Nonetheless his analyses, though partial, are a valuable tool for an endeavour to understand.
\end{abstract}

Keywords: Muslim society, fundamentalism, civil society, secularization, failure of Marxism

Zájem o problematiku islámu, jeho obrazu světa a reálného uspořádání společnosti prostupuje významnou část Gellnerova sociálně-filozofického a antropologického díla. Gellner na tomto poli často vyhledává komparativní nebo explikativní materiál ke svým úvahám o společnosti západní a také o závažných obecných otázkách moderní doby. Jde zejména o pět tematických okruhů, které se ovšem v systematice jeho myšlení navzájem propojují:

1. Dvojpólovost religiozity, kdy dochází k ustrnutí kyvadla v poloze, která vymezuje novodobý islámský fundamentalismus. Viz Gellnerovy práce Saints of the Atlas (1969); Muslim Society (1981); Postmodernism, Reason and Religion (1992).

2. Podstata fundamentalismu v obecné filozofické a konkrétní islámské podobě (práce Postmodernism, Reason and Religion).

3. Muslimská společnost a nacionalismus v knize Nations and Nationalism (1988) a v přednášce „Religion and the Profane“, proslovené v Heidelberku v ř́ijnu 1995.

4. Islám a občanská společnost v publikacích Civil Society in Historical Context (1991) a Conditions of Liberty (1996).

5. Překvapivé výsledky vývoje islámu a marxismu ve 20. století (Conditions of Liberty; předmluva k Akbar S. Ahmed - Hastings Donnan: Islam, Globalization and Postmodernity (1994); již zmíněná přednáška „Religion and the Profane“.

Přestože Ernesta Gellnera při vší jeho široké erudovanosti nelze označit za arabistu nebo islamologa, jeho pohledy na sociální podstatu a moderní vývojové trendy islámu přinesly do této badatelské oblasti řadu podnětů, bez nichž si dnešní sociálně-antropo-

* Prof. Luboš Kropáček, Filozofická fakulta Univerzity Karlovy, Náměstí Jana Palacha 2, 11638 Praha 1. E-mail: kroplaff@praha1.ff.cuni.cz 
logické studium islámu vlastně ani nelze představit. Povšimněme si alespoň hlavních Gellnerových myšlenek na tomto poli, jejich inspirativních částí i jejich nejistot a slabin.

\section{Dvojpólovost}

Myšlenkám propracovaným v prvém z pěti uvedených okruhů Gellner sám přikládal zásadní význam. V jeho pracích a komentářích početných autorů, kteří se jeho myšlenkami zabývali, se jako výklady dnešního islámu v souhlasných, modifikujících i polemických pojetích bohatě rozšírilly. $\mathrm{V}$ české islamologii se jim věnoval zejména autor této studie [Kropáček 1996: 48-50; Kropáček 2008: 299-308]. Ke klíčové koncepci dvojího typu religiozity v muslimské společnosti přivedly Ernsta Gellnera podle jeho vlastních slov především tři soubory podnětů: filozofická dichotomie v dějinách a společnosti, jak ji vyložil v Muqadddimě Ibn Chaldún, protestantsky motivovaná teorie náboženství, kterou kdysi předložil David Hume v Natural History of Religion, a poznatky, k nimž dospěl Gellner sám při terénním antropologickém výzkumu v maghribských zemích, zvláště v Maroku. Shrnula je monografie Saints of the Atlas [Gellner 1969], na jejíž zjištění praktikovaná dichotomie navázala v zobecňujícím zevrubném promyšlení Muslim Society [Gellner 1981: 7-21]. ${ }^{1}$ Duchovní, politické a strukturální rozpolcení společnosti, na jaké upozorňovali Ibn Chaldún a David Hume, v naší moderní době významný sociální filozof působící tehdy v Cambridgi, Gellner vyložil v aplikaci na muslimskou společnost jako oscilaci mezi městskou, př́sně monoteistickou verzí islámu, opřenou stroze o Písmo, tj. o Korán, a verzí venkovských kmenů se silnou rolí súfijských šejchů. Tuto, dnes dominující verzi, pokládal za přijímanou jako vhodnější v městské společnosti, otevírající více prostoru individualismu. Výkladový model dovedený k formulační přesnosti v Muslim Society Gellner př́ležitostně rozvíjel jako odpověd’ na aktuální otázky, jež přinášela rostoucí aktivita radikálních muslimských myšlenkových a politických proudů. Své pojetí zahrnoval do výkladu pojmu fundamentalismu, který od sedmdesátých let nabýval na frekvenci v diskuzích o soudobém islámu. Gellner ukázal, jak si atomizace lidí v urbanizujících se společnostech vyžaduje moralistické a individualistické pojetí víry, tedy vyšší, Koránem zaštítěný islám. Charakterizoval jej řadou adjektiv: víra skripturalistická, legalistická, puritánská, střízlivá, antiextatická [Gellner 1997: 21]. Nalézal zde také osnovu k výkladu vitality islámu oproti dobovému sekularismu a k vymezení jeho místa a pravděpodobných perspektiv. Jeho ,,dvojpólový“ model silně zapůsobil na velkou část odborníků zabývajících se islámským myšlením, sociologií a politologií, a to jak přitakavě, tak polemicky. Metafora o kyvadle, které ustrnulo v jediné $\mathrm{z}$ dosavadních protilehlých úvratí, patřila $\mathrm{k}$ nejdiskutovanějším tématům již od šedesátých let. Bylo formulováno i odlišné pojetí dvojpólovitosti: proti aktivismu radikálů představa kontemplativního kvietismu mystiků. A na poli sociální a kulturní antropologie byl proti Gellnerovu bádání o segmentárních společnostech postaven př́stup stoupenců Clifforda Geertze s primárním důrazem na hodnoty. ${ }^{2}$ Marocký tradiční model vzdoru (siba) vůči centrální moci byl komparativně vztažen $\mathrm{k}$ dalším obdobným případům disidence $\mathrm{v}$ Africe i zcela mimo oblast islámu.

1 Eseje v této knize Ernest Gellner redigoval již v letech 1967-1979.

2 Stručný přehled kritických přístupů ke Gellnerovu modelu nabídl Jean-Claude Vatin v příspěvku „La part politique de l’Islam“, který přednesl na francouzsko-českém kolokviu pořádaném Univerzitou Karlovou a pařížským École des hautes études en sciences sociales (EHESS) na Filozofické fakultě Univerzity Karlovy v listopadu 1997 pod názvem „Přemýšlení s Gellnerem“. 
Pokud Gellner přemýšlí o súfismu, má na mysli pouze jeho sociální projevy. Téměř zcela ponechává mimo své obzory spirituální výše i hloubky islámské mystiky a dokonce ani jeho sociální záběr nemůže být přijímán jako úplný. Zajímala ho hlavně personifikovaná vedení súfijských taríq, a to především v segmentárních společnostech. Ibn-chaldúnovské rozlišování městských a venkovských kultur ho přitom vedlo k poměrnému opomíjení skutečnosti, že v osmanském období se rozmanité formy súfismu výrazně prosadily též ve městech, a to i v prostředí vzdělaneckých elit. I tato varianta se ovšem skutečně dostala za islámského „reformismu“ konce 19. a pak 20. století do konfliktu s „fundamentalismem“ prosazujícím vyšší koránské pojetí.

Emeritní profesor politologie a sociologie na Londýnské univerzitě Sami Zubaida podrobil Gellnerovu tezi i s částmi jejího následného rozvíjení zásadní kritice. Vidí v jeho pohledu na islámskou společnost esencialistické pojímání islámu, které neodpovídá velmi pestré rozmanitosti reálných muslimských společností v jejich dějinách. Gellnera tak jako všechny esencialistické argumentace kritizuje za ahistoričnost, za nedoceňování významných politických a sociálních rozdílů patrných v islámské historii [Zubaida 2003: 118; pro rozsáhlejší polemiku Zubaida 1995]. Stojí za povšimnutí, že oba autoři mají obdobné oborové zaměření, avšak Zubaida věnuje podstatně více pozornosti právní problematice než Gellner. Ten tuto stránku dnešního islámského radikalismu, horlícího pro šaríu, poněkud nedoceňuje.

\section{Fundamentalismus}

Pojem, který se většinou s negativními konotacemi rozšíril od sedmdesátých let, byl a je dodnes aplikován velmi často na islám. Muslimští intelektuálové se mu bránili, zpravidla s poukazem na skutečnost, že pojem vznikl v protestantském prostředí ve Spojených státech. Do arabštiny byl převeden kalkem usúlija ${ }^{3}$ dnes ho vytlačuje nově pojatý termín neúprosného konzervativismu odvolávajícího se na vzor chování prvních muslimských generací „,tihodných předkư“, salafíja, salafismus. Před islamology vyvstává otázka, zda fundamentalismus patří bytostně k islámu (hanbalovský právní a teologický směr?), nebo zda jde o jev zásadně moderní [pro výklad pojmu s četnými západními i muslimskými variacemi Kropáček 1996: 11-57]. V tomto směru se angažuje zejména Johannes J. G. Jansen, který v islámském fundamentalismu vidí plné splynutí náboženství a politiky [Jansen 1997].

Gellner zařadil obecně chápaný pojem fundamentalismu do filozofického schématu, které podal v monografii Postmodernismus, rozum a náboženství [Gellner 1992]. Schéma se zabývá třemi konkurenčními pojetími pravdy, nabízenými dnešnímu člověku. První je fundamentalismus, založený na nároku na exkluzivní majetnictví pravdy v její celistvé úplnosti. Tomuto přesvědčení konkurují postmoderní relativismus a osvícenský racionalismus. Ten sice na rozdíl od relativismu s fundamentalismem sdílí souhlas, že existuje pravda, avšak neosobuje si více než pozvolné poznávání cest, jež k ní směřují. Pro dnešní politické a intelektuální klima je příznačné, že svůj výklad fundamentalismu Gellner založil právě na jeho islámské verzi jako na snadno zkoumatelném názorném

3 Usúl znamená arabsky ,základy“. Novodobý kalk usúlíja naráží však v islámském diskursu na matoucí paradox, že v šíitské institucionalizaci a terminologii usúlíja vyhrazuje prostor rozumovému idžtihádu, zatímco k fundamentalismu tíhne naopak její protiklad achbáríja. 
př́kladu. Spojení náboženství a politiky, které předváděl již ve svém modelu, má i v tomto výkladu své místo. Cílem snah fundamentalistů, tedy islamistů, je ,,(..) existující vysoká kultura (...) vybavená politickým zastřešením, jež je jí hodno (...) [Gellner 1994: 115].“

\section{Muslimská společnost a nacionalismus}

Gellner si samozřejmě uvědomoval, jak složité, proměnlivé a nejednotné jsou a vždy byly muslimské společnosti. Nemohou být tedy mechanicky vykládány podle jediného schématu. Ve 20. století a zvláště pak za konečného rozpadu koloniálních impérií po 2. světové válce nebylo možné muslimské arabské i další asijské a africké společnosti vnímat bez zřetele k silně působícímu faktoru nacionalismu. Gellner mu věnoval náležitou pozornost i s historickým ponorem do zvláštností muslimských společenských systémů. Jako zřetelně specifické modely uvádí režimy mameluků a Osmanské řŕše, založené na politické moci vojenských a byrokratických elit přisouvaných cílevědomě z cizího prostředí. V monografii Národy a nacionalismus věnuje této tematice zvláštní pozornost při rozboru vládních systémů agrárních států [Gellner 1988; v českém překladu Gellner 1993: 25-27]. ${ }^{4}$ Se svým vytříbeným jemným humorem Gellner takovéto využívání cizinců bez místních rodových vazeb - a tedy loajálních vůči suverénní moci a nepředstavujících nebezpečí místně podnícených převratů - označuje vtipně a dobře zapamatovatelně jako režimy vykleštěných valachů oproti hřebcům, působícím v jiných systémech.

Tato praxe neměla již ovšem ve 20. století někdejší význam. Arabský i etnicky jiný nacionalismus v širším nebo užším pojetí hrál svou politickou roli. Stojí za připomenutí, že Gamál Abd an-Násir se stal po dlouhé řadě generací od starověku prvním vládcem Egypta domácího původu. Za zmínku také stojí, že moderní nacionalismus byl islamistickými proudy vnímán často jako nedobrá konkurence k islámské politice. Gellner, věrný svému základnímu modelu, zjištuje, že vysoká kultura spjatá s gramotností nabývá postavení kultury celospolečenské a vyjadřuje ji nacionalismus; v muslimských společnostech se však toto vyjádření děje v islámském fundamentalismu [Gellner 1994; v českém překladu Gellner 1997: 25].

Nelze si však nevšimnout, že nacionalismus a islamismus se dnes na některých místech spojují. ${ }^{5} \mathrm{~V}$ turecké verzi se durkheimovský kult společnosti uskutečňuje - řečeno Gellnerovými slovy - nikoli prostřednictvím náboženství, ale ,,bezostyšně přímo““ ${ }^{6}$

Prorůstání nacionalismu s původním náboženským základem není Gellnerovým velkým zájmem, i když je naznačuje ve svém poslední tematickém okruhu při diskuzi o sekulárním a profánním.

Gellner vidí, že organizované vzdělání zahrnuje dnes ve většině muslimských zemí celou společnost, týká se jejich individualizovaných členů. Sám nacionalismus je ale vystaven postupné erozi pod tlaky různorodých tendencí moderního světa. Jeho

4 Práce Nations and Nationalism patří na univerzitách v západní Evropě k nejužívanější literatuře zadávané posluchačům sociálních věd.

5 Bylo by možné uvést řadu př́íkladů od některých tendencí alžírského zápasu o nezávislost až po dnešní palestinský Hamás.

6 Gellnerova Předmluva (Foreword) ke sborníku editovaného Akbarem S. Ahmedem a Hastingsem [Gellner 1994: xiii]. K tématu zvláštní a měnící se povahy tureckého sekularismu publikoval nedávno výstižnou analýzu Erik Siegl, Proměny a kontinuita ve vývoji tureckého sekularismu. Mezinárodní vztahy 45 (2010), číslo 2, s. 123-134. 
slábnutí předvídali liberálové i marxisté, byt každý v jiném výkladovém schématu. Gellner výstižně upozorňuje na rozmanitost nacionalistické zkušenosti (Podmínky svobody), a ukazuje tak na rozkolísanost hodnot v dnešním světě.

\section{Občanská společnost}

Ke Gellnerovu základnímu dvojpólovému modelu islámské společnosti, narušenému moderní reformou přinášející obecně závaznou strohost fundamentalistického, na Koránu založeného modelu, se přimyká jako další kontroverze spor o možnost vytvářet a rozvíjet v muslimském prostředí občanskou společnost. Gellnera téma občanské společnosti silně zajímalo. Rozebíral je ve vztahu k západním společnostem a muslimské společnosti mu sloužily jako markantní protiklad. Jeho celou monografii Podmínky svobody prostupují skeptické názory na možnost rozvinout občanskou společnost v muslimských zemích. Podle jeho názoru tu za nadbytkem náboženské víry, silným až dusivým, není k dispozici ani potřebný prostor, ani skutečné přání [Gellner 1997]. ${ }^{7}$ V mírnější, ale stejně záporné formulaci Gellner prohlašuje: „(m)uslimský svět (...) je příznačný pružností své formální víry, a když vůbec nějakou, tak pouze slabou touhou po občanské společnosti [Gellner 1997: 18]. “ Nemůžeme si tu nepovšimnout, že mu jaksi uniká přítomnost a význam islámských liberálních sil. V jeho obrazu tak chybí některé barvy a odstíny, zřetelně nebo potenciálně vlivné a perspektivní.

Spor o perspektivu či nereálnost občanské společnosti v muslimských zemích má větší počet nestejně vyostřených variant. Autor této studie perspektivu hájí a propojuje s diskuzemi v arabských médiích a myšlenkových centrech [Kropáček 1999: 129-141] i s výsledky podrobných výzkumů prováděných pod vedením Augusta R. Nortona [Norton 1995-1996]. Spor zazněl i na zmíněné česko-francouzské akademické konferenci „Přemýšlení s Gellnerem“ v roce 1997. Proti stoupencům ortodoxních gellneriánů a klasických intencí Adama Fergusona se kromě autora těchto řádků postavila také Gellnerova žákyně z Velké Británie, antropoložka Madawi Al Rasheed (v daném kontextu v Nortonově sborníku zřejmě s rozpaky opomenutá), která vidí pozitivní vyhlídky i v Saúdské Arábii, jež je její vlastí a důležitým tématem výzkumů. Spor se znovu objevil i v knize reflexí vyvolaných známým sociologem náboženství Peterem Bergerem k tématu náboženství a občanské společnosti. Vyslovené názory českých odborníků tvoří dosti široké spektrum. Tématem, včetně polemiky s Gellnerem, se tu zabývá autor této studie, vyslovující souhlas s Bergerovým souhrnným soudem, že žádná obecná odpověd’ na otázku náboženství a občanské společnosti neexistuje. Miloš Mendel pokládá občanskou společnost v islámských zemích za nereálnou představu. Argumentuje hlavně tím, že jde o cosi, co je tu nepotřebné [Kropáček 2008; Mendel 2008].

Je zde namístě znovu připomenout i kritiku esencialistického pojímání muslimské společnosti, kterou stíhal Gellnera Sami Zubaida. Je nepochybné, že islám a jím ovlivňované politické a sociální formace nelze vnímat jako homogenní. Dodejme však, že muslimské společnosti mohou ve svých ideálních představách - o reálném životě zde není řeč - těžko přijímat konec morálního řádu, který občanské společnosti připisuje Gellner. Pro muslimy je takovéto pojetí jen tématem ke kritice Západu. Sami se mohou

$7 \quad$ Často se také cituje Gellnerovo př́kré odmítnutí perspektivy občanské společnosti v muslimských zemích z jeho stati „Civil Society in Historical Context“ [Gellner 1991: 506]. 
a musí opírat o koránskou nauku o závažnosti role obce či státu, jakou je přikazovat vhodné a zakazovat zavrženíhodné.

[Korán 3:104 a 110, 9:71, 31:57].

\section{Výsledky marxismu a islámu}

Gellner pozorně sledoval konstantní i proměňující se projevy islámu, postupně stále silněji ovlivňující postmoderní svět. Svým dvojpólovým modelem se pokusil podat i odpověd’ na otázku, proč se islám nevydal cestou sekularizace, jaká podle převažujícího západního názoru nutně patří k modernitě. Pádněji pak sílu dnešního islámu a jeho odolnost vůči sekularizaci, tedy vůči vytěsňování náboženství z veřejné sféry, vyjádřil v Předmluvě ke knize Akbara S. Ahmeda a Hastingse Donnana, kde podle původní představy měl patřit ke spoluautorům [Gellner 1994: xi-xiv, pozn. 15]. Téma triumfujícího nesekularizovaného islámu a zhroucení marxismu, nejednou označovaného za sekulární či politické náboženství Gellner pak s důrazem a svou rétorickou obratností vyložil ve své přednášce v Heidelberku v říjnu $1995 .{ }^{8}$ Nikdo netušil, že šlo pravděpodobně o jeho poslední text; v listopadu 1995 ho v Praze zastihla smrt.

Na sklonku století Gellner vidí jevy, které se jeví jako paradoxy a nejsou snadno vysvětlitelné. Na jedné straně marxismus, který po velkou část století vystupoval jako velká síla budoucnosti, se zhroutil. Jeho selháním se zabývají již výklady v Podmínkách svobody. Na troskách sovětského impéria se mohou sice místy ozývat nostalgické povzdechy, jako doktrína, která by dokázala nadchnout a směrovat srdce a mysli lidí, marxismus však neobstál. Na druhé straně islám prokázal sílu a pozoruhodnou životaschopnost. Gellner tento zdánlivý paradox vykládá nedostatkem docenění profánní stránky života v politickém náboženství marxismu, který sakralizuje práci jako cestu ke svaté blaženosti komunistického lidstva tohoto světa v budoucnosti. Gorbačov však nadzvedl víko nad nesmírností iluzí, které dříve zastíraly stalinský teror a brežněvovská stagnace. Naproti tomu islám profánní rozměr tohoto světa akceptuje. Nikdy nepřisuzoval práci sakrální dimenzi. Tu má pevně zabudovánu v náboženské transcendentní víre.

Bylo by užitečné srovnat Gellnerovo pojetí s poněkud odlišně koncipovaným výkladem jednoho z nejvýznamnějších evropských konvertitů k islámu Rogera Garaudyho. Ten nadřazuje islám marxismu proto, že razí v rétorice i ortopraxi cestu sociální spravedlnosti a zároveň uznává transcendentní duchovní hodnoty. ${ }^{9}$ Gellner ve svém střízlivém realismu označuje za dnešní představitele úspěchu pluralitní, liberální společnosti. Nazývá ji nesvatou aliancí ke konzumu orientovaných nevěřících. Vedle obecné tendence ke spotřebě a prosperitě pojímají spásu a ctnost privatizovaně. Neostýchá se hovořit s pozitivními akcenty o konci morálního řádu. Jaký bude další vývoj, případně zda technické inovace pomohou účinně zvládnout materiální bídu v částech světa, to Gellner ponechává jako otevřenou otázku.

8 Přepis této přednášky s titulem „Religion and the Profane“ publikoval Newsletter (Institut für die Wissenschaften vom Menschen), No. 58 (July-October 1997), s. 21-24.

9 Roger Garaudy prodělal podivuhodný myšlenkový vývoj. Někdejší člen politbyra komunistické strany Francie, po období zájmu o křestanské hodnoty přešel k islámu, kde se mu dostalo vysokého ocenění. Svými spisy i působením v mezinárodní Radě mešit i z centra ve španělské Córdobě Garaudy přináší zvláštní příspěvek k evropsko-muslimskému dialogu. 


\section{Závěr}

Jestliže poslední přednesený Gellnerův text končí náznakem nejistoty, je to příznačná tečka. Se svým sklonem k Popperovu pojetí opatrnosti při hledání pravdy by Gellner pravděpodobně kritické výtky, jež jsou jeho názorům dodnes porůznu adresovány, přijímal vlídně a přemýšlivě. Naše kritické připomínky v tomto přehledném textu se soustředují hlavně na zužující optiku některých jeho úvah, které tak podle našeho soudu nereflektují dostatečně plnou šíri zkoumaných islámských nábožensky podložených jevů, představ a postojů. Súfijský pól islámu zánikem tradičních pospolitostí a likvidačními kampaněmi (vedenými leckde dodnes) nezanikl, ale lze doložit i jeho vlastní modernizaci.

Postoj otevřenosti a postupu k pravdě, jaký Gellner, oslněný osvícenstvím, připisuje pouze moderní západní vědě, je tř̌eba přiznat i některým proudům náboženského myšlení, a to jak v křestanství, ${ }^{10}$ tak v islámu. Setkáme se tam s ním nejspíše u některých intelektuálských osobností, jejichž působení zaniká v halasení médií o radikálech. Konkrétní fakta svědčí také o tom, že Gellner nedocenil existenci liberálních proudů v muslimských společnostech, z nichž se ustavuje i zvláštní větev formující se občanské společnosti. V městském prostředí se přitom za politických, sociálních i kulturních střetů tvoří nová rozštěpení až rozkoly (arabsky označené fitna), odlišné od dichotomie, na níž Gellner stavěl v určité historické a sociální perspektivě svou důležitou tezi. K otázce morálního řádu, který Gellner viděl negativně jak v marxistickém, tak islámském pojetí, lze znovu dodat, že Gellnerovo vlastní pojetí lze vnímat jako redukci. Vedle kritiky západní bezbřehosti si tu jistě zasluhuje kritiku také islámské totalitní pojetí s jeho výstřelky i pedantskými malichernostmi. Je to výzva pro křestany, kteří mohou osvědčit kritickou vnímavost k oběma stranám konfliktního napětí [Kropáček 2005: 152-155; k obecnému postoji ke Gellnerově ,neúplnosti“ viz také Kropáček 2008: 305-308]. Takové hledisko ovšem Gellner do svého obrazu nezařazuje. Jeho reflexe islámu působí nicméně ve svém celku i v početných jednotlivostech nadále inspirativně.

10 Pozornost si zaslouží křestanská formulace, že „Pravda zůstává 'nad’ námi a 'před námi' - a v tom je naše naděje uprostřed klamu a lži. “ In: Šrobár, Štefan: Biblické pojetí pravdy. Perspektivy 12 (2010), číslo 23 , s. 1 . 


\section{Literatura}

Ahmed, Akbar S. - Hastings, Donnan (eds.). [1994]. Islam, Globalization and Postmodernity. London - New York: Routledge.

Dekmejian, R. Hrair. [1985]. Islam in Revolution. Fundamentalism in the Arab World. Athens: Syracuse University Press.

Gellner, Ernest. [1969]. Saints of the Atlas. Chicago: University of Chicago.

Gellner, Ernest. [1981]. Muslim Society. Cambridge: Cambridge University Press.

Gellner, Ernest. [1988]. Nations and Nationalism. Oxford: Blackwell.

Gellner, Ernest. [1993]. Národy a nacionalismus. Praha: Hř́bal.

Gellner, Ernest. [1991]. Civil Society in Historical Context. International Social Science Journal 43 (August 1991), No. 3, s. 495-510.

Gellner, Ernest. [1992]. Postmodernism, Reason and Religion. London - New York: Routledge.

Gellner, Ernest. [1994a]. Conditions of Liberty. Civil Society and Its Rivals. London: H. Hamilton.

Gellner, Ernest. [1994b]. Foreword. In. Ahmed, Akbar S. - Hastings, Donnan (eds.). [1994]. Islam, Globalization and Postmodernity. London - New York: Routledge, s. X-1.

Gellner, Ernest. [1997]. Podmínky svobody. Občanská společnost a její rivalové. Brno: CDK.

Hanuš, Jiří - Vybíral, Jan (eds.). [2008]. Náboženství v globální občanské společnosti. Brno: CDK. Janssen, Johannes J. G. [1997]. The Dual Nature of Islamic Fundamentalism. London: Hurst \& Co. Kepel, Gilles. [1991]. La revanche de Dieu. Paris: Seuil.

Korán. Praha: Odeon, 1972.

Kropáček, Luboš. [1996]. Islámský fundamentalismus. Praha: Vyšehrad.

Kropáček, Luboš. [1991]. Blízký východ na přelomu tisíciletí. Praha: Vyšehrad.

Kropáček, Luboš. [2002]. Islám a Západ. Historická pamět a současná krize. Praha: Vyšehrad.

Kropáček, Luboš. [2005]. Dnešní islám a otázky mravního ráádu. Teologické texty 16 (2005), číslo 4, s. $152-155$.

Kropáček, Luboš. [2008a]. Súfismus. Dějiny islámské mystiky. Praha: Vyšehrad.

Kropáček, Luboš. [2008b]. Komentář, převážně islamologický. In. Hanuš, Jiří - Vybíral, Jan. (eds.). Náboženství v globální občanské společnosti. Brno: CDK, s. 115-120.

Lücke, Hanna. [1993]. „Islamischer Fundamentalismus“ - Rückfall ins Mittelalter oder Wegbereiter der Moderne? Berlin: K. Schwarz Verlag.

Mendel, Miloš. [2008]. Občanská společnost v islámských zemích - nereálná představa. In. Hanuš, Jiří - Vybíral, Jan. (eds.). Náboženství v globální občanské společnosti. Brno: CDK, s. 33-41.

Norton, Augustus R. [1995-1996]. (ed.) Civil Society in the Middle East. Leiden - New York - Köln: E. J. Brill, 2 Vols.

Roy, Oliver. [1990]. De l'islam révolutionnaire au néofondamentalisme. Esprit No 163 (juillet-août 1990), s. 5-14.

Zubaida, Sami. [1995]. Is there a Muslim society? Ernest Gellner's sociology of Islam. Economy and Society 24 (May 1995), No. 2, s. 155-181.

Zubaida, Sami. [2003]. Law and Power in the Islamic World. London: I. B. Tauris.

Prof. Luboš Kropáček (1939), orientalista. Přednáši na Univerzitě Karlově na Filozofické fakultě a teologických fakultách. Vydal několik knih o islámu, zvláště Duchovní cesty islámu (4. vydání 2006), Islámský fundamentalismus (1996), Blízký východ na přelomu tisíciletí (1999), Islám a Západ (2002) a Súfismus. Dějiny islámské mystiky (2008). 